\title{
Article \\ Detection of Preferential Water Flow by Electrical Resistivity Tomography and Self-Potential Method
}

\author{
Karlis Kukemilks * and Jean-Frank Wagner (D) \\ Department of Geology, University of Trier, Behringstraße 21, D-54296 Trier, Germany; wagnerf@uni-trier.de \\ * Correspondence: kukemilks.karlis@inbox.lv; Tel.: +49-651-201-4644
}

Citation: Kukemilks, K.; Wagner, J.-F Detection of Preferential Water Flow by Electrical Resistivity Tomography and Self-Potential Method. Appl. Sci. 2021, 11, 4224. https://doi.org/ 10.3390/app11094224

Academic Editor: Filippos Vallianatos

Received: 30 March 2021

Accepted: 29 April 2021

Published: 6 May 2021

Publisher's Note: MDPI stays neutral with regard to jurisdictional claims in published maps and institutional affiliations.

Copyright: (c) 2021 by the authors. Licensee MDPI, Basel, Switzerland. This article is an open access article distributed under the terms and conditions of the Creative Commons Attribution (CC BY) license (https:// creativecommons.org/licenses/by/ $4.0 /)$.

\begin{abstract}
This study explores the hydrogeological conditions of a landslide-prone hillslope in the Upper Mosel valley, Luxembourg. The investigation program included the monitoring of piezometer wells, hydrogeological field tests, analysis of drillcore records, and geophysical surveys. Monitoring and field testing in some of the observation wells indicated very pronounced preferential flow. Electrical resistivity tomography (ERT) and self-potential geophysical methods were employed in the study area for exploration of the morphology of preferential flowpaths. Possible signals associated with flowing groundwater in the subsurface were detected; however, they were diffusively spread over a relatively large zone, which did not allow for the determination of an exact morphology of the conduit. Analysis of drillcore records indicated that flowpaths are caused by the dissolution of thin gypsum interlayers in marls. For better understanding of the site's hydrogeological settings, a 3D hydrogeological model was compiled. By applying different subsurface flow mechanisms, a hydrogeological model with thin, laterally extending flowpaths embedded in a porous media matrix showed the best correspondence with field observations. Simulated groundwater heads in a preferential flow conduit exactly corresponded with the observed heads in the piezometer wells. This study illustrates how hydrogeological monitoring and geophysical surveys in conjunction with the newest hydrogeological models allow for better conceptualization and parametrization of preferential flow.
\end{abstract}

Keywords: preferential flow; resistivity tomography; self-potential mapping; hydrogeological modeling

\section{Introduction}

The aim of this study is the identification and characterization of preferential flow in a study site by using hydrogeological and geophysical investigation techniques. Field investigation delivers boundary conditions for groundwater simulation, which allows for better characterization of preferential flow in the subsurface.

Preferential groundwater flow has been extensively studied in recent decades because it has a growing importance in several research fields such as in contaminant transport [1], the construction of nuclear waste repositories [2,3], the prevention of dam leakages $[4,5]$, and in slope failures [6-9].

Various types of discontinuities in rock or soil such as surface or subsurface layer topography, tree root decay, animal caves, or soil/rock cracks can result in preferential flow $[10,11]$. Preferential flow routes can form complex networks [12], and moreover, they can evolve over time [13].

Recent advances in numerical modeling allow for the consideration of preferential flow in hydrogeological simulations [14,15]. Beven and Germann [16] identified the following preferential flow modeling approaches: single continuum, dual continuum, dual permeability, and dual porosity. In the case of single continuum, dual continuum, and dual permeability modeling approaches, the morphology of separated fractures is not represented in the model. Instead, modified hydraulic conductivity functions for single continuum models or regularly distributed permeable inclusions are applied to the 
model [16]. Such an approach allows for the consideration of the impact of preferential flowpaths in a generalized way if the impact of individual conduits can be neglected.

The dual-porosity approach considers the morphology of individual flowpaths, and the water exchange between the conduit and the encompassing matrix is simulated [16]. However, this approach is numerically challenging and demands advanced investigation techniques for the identification and parametrization of the preferential flow conduits in the subsurface. Consequently, depending on the demanded model's resolution, an appropriate approach of preferential flow conceptualization in the model should be selected. Data characterizing preferential flow in the field site can be attained by selecting appropriate field investigation techniques, and they are a prerequisite for the building of a representative groundwater model.

Various geophysical and hydrogeological approaches have been used recently for the identification of preferential flow pathways [17-22]. The main hydrogeological approaches are single-borehole tests, hydraulic tests, cross-borehole hydraulic tests, and tracer tests [23]. However, these methods have limited applicability if the groundwater-bearing fracture is not in the proximity of the borehole [17].

Non-invasive geophysical techniques such as electrical resistivity tomography (ERT) have been widely applied for the investigation of lithological settings $[18,19]$ and groundwater bodies [20,21,24,25]. ERT determines the resistivity distribution in the subsurface, which allows for the identification of saturated zones of soil and rock. Both the flow of groundwater and of electrical current in saturated rock or soil rely on similar physical principles, which can be conceptualized through the flow in porous and fractured media [24]. The conduits within the rock matrix can radically increase conductivity both in terms of water and electrical current $[6,24,26]$. By using the discrete-dual-porosity modeling approach, the impact of anisotropy on the electrical resistivity of rock massif has been illustrated [24]. It should be added that anisotropy of electrical conductivity in subsurface is affected by other factors such as solute concentration variability. This effect is particularly emphasized under partially saturated conditions [27].

Preferential flowpaths can be caused by different types of heterogeneities in the subsurface. Without discrete fracture networks, as discussed before, highly permeable interlayers, subsurface layer topography, or animal burrows can serve as preferential flowpaths as well $[10,11]$. The integrated use of geophysical and subsurface monitoring techniques increases the accuracy of geophysical surveys for application in different scales and geological settings. The combined use of ERT and active seismics allowed for monitoring of water flow in the vadose zone with very high spatial and temporal resolution [28].

The effect of groundwater flow in fractured media on electrical resistivity distribution and streaming potential signals has been modeled numerically $[24,26]$. For this research, we have selected ERT and self-potential techniques that provide a physical link both with water content and water flow in the subsurface [24,26,28].

A self-potential geophysical method using non-polarizing electrodes has been employed for measuring the streaming potential associated with preferential flow paths $[18,29-33]$. Contrary to ERT, when an external source of current is applied, the self-potential method measures electrical charges developing naturally in the subsurface [34-36]. There are various sources of self-potentials. Redox potentials cause the most pronounced self-potential anomalies up to $1500 \mathrm{mV}$ [37]. Anomalies caused by streaming potentials have lower magnitude, and they are generated by electrolytic groundwater flowing in porous or fractured media $[35,36]$. Water in the space between mineral grains is never neutral, as there is an excess of charge in pore water to balance the charge on the surface of silicate and aluminosilicate mineral particles [35]. The presence of the excess charges in pore water causes the phenomenon of streaming potential when the charges are dragged by flowing groundwater. As a consequence, in unconfined aquifers, positive self-potential anomalies can be observed in the direction of the preferential flow [18,35].

The literature review shows that preferential flow has an importance in many fields because it can radically alter the velocity and rate of groundwater flow. The newest 
hydrogeological models are able to consider various kinds of preferential flow mechanisms in a groundwater simulation. However, advanced investigation and testing in the field site is a prerequisite for the adequate conceptualization and parametrization of the preferential flowpaths in numerical models.

This study was conducted in the study site of Deisermillen (Luxembourg), Upper Mosel region (Figure 1a), where in the autumn of 1964, a dangerous landslide occurred [38,39]. The typical morphological features of the landslide such as hummocky topography can be seen in a high-resolution digital elevation model (Figure 1b).

In 1965, several drillings were done under the supervision of the State Geological Survey [39] in order to investigate the possible causes of the Deisermillen landslide. In 1974, additional fieldworks were done to conduct remediation measures in the landslide's area [40]. From previous research campaigns, 11 borehole records in all are available in the Archive of Geological Survey of Luxembourg [39,40]. In 2018-2019, an extensive field research program was conducted including 8 new geological drillings, hydrogeological monitoring and testing, and geophysical exploration to investigate the lithological and hydrogeological setting of the landslide's area. All of the borehole records from previous and actual studies were used for the geological characterization of the study area and the building of a 3D geological model (Figure 1c,d).

The uppermost lithological sequence in the study area is the dolomites of the Upper Muschelkalk (mo). This formation appears as a steeply inclined cliff in the western part of the site (Figure $1 \mathrm{~b}-\mathrm{d})$.

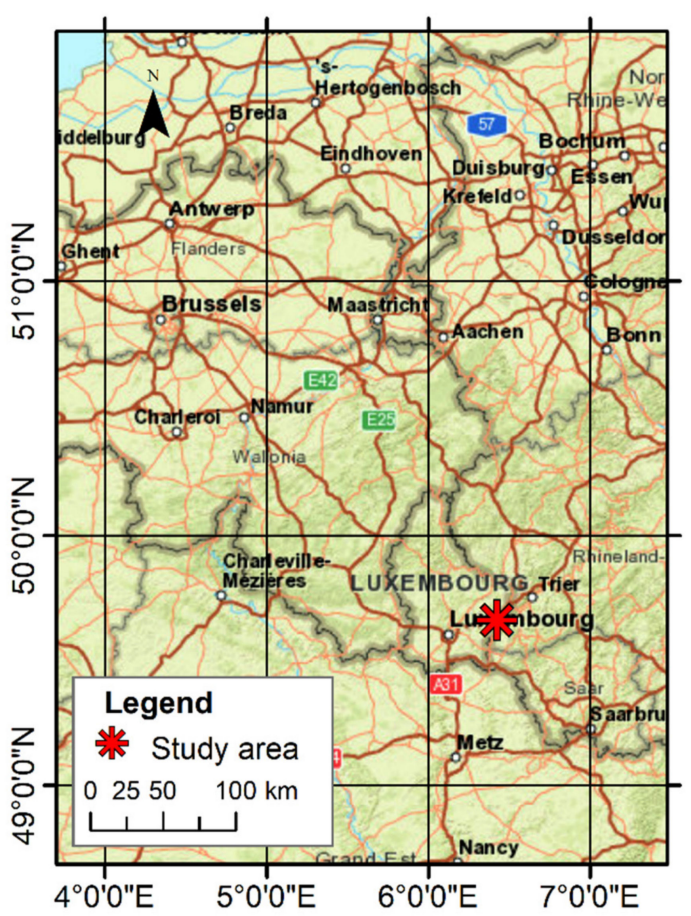

(a)

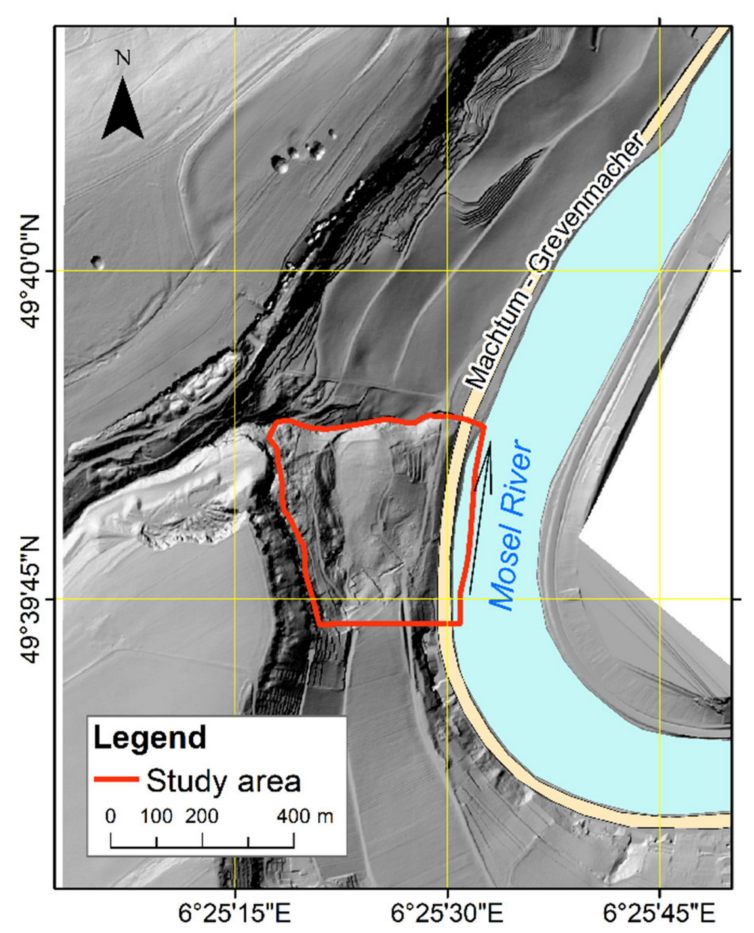

(b)

Figure 1. Cont. 


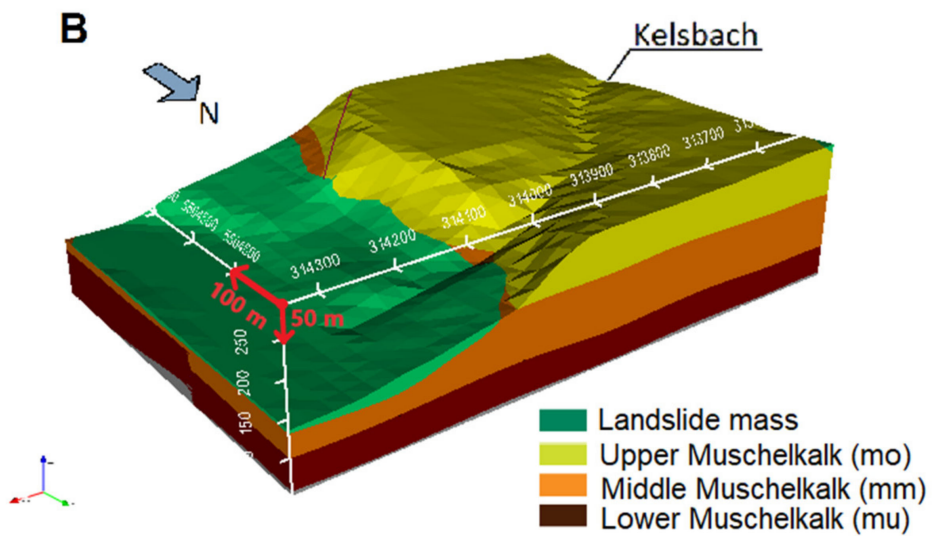

(c)

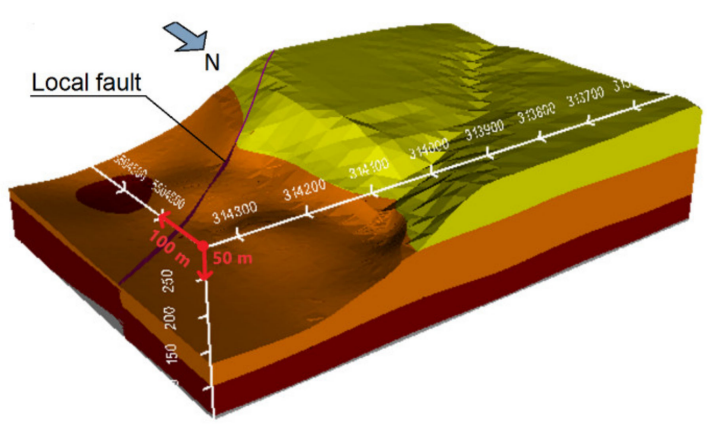

(d)

Figure 1. (a) Regional location of the study area (modified after [41]), (b) hillshade map showing location of the study area affected by the landslide in the Mosel River valley, a 3D geological model of the study area (c) with and (d) without landslide mass cover (processed from [42,43]).

This formation is underlain by a $70 \mathrm{~m}$ thick Middle Muschelkalk ( $\mathrm{mm}$ ) formation composed of gypsiferous marls. These marls are covered by the 6 to $14 \mathrm{~m}$ thick, less consolidated, landslide mass extending from the Mosel River to the Upper Muschelkalk cliff (Figure 1c). The landslide mass cover consists of dolomite blocks embedded in a silty matrix. The landslide mass, through which the landslide occurred, was formed during a long-term morphological evolution of the hillslope by alteration and erosion of the Middle Muschelkalk marls and rockfall of dolomite blocks from the Upper Muschelkalk cliff. There is a local fault trending in a SW-NE direction along the southern border of the study area (Figure 1d). It can be assumed that the fault marks the maximal extension of the landslide to the south as more resistant rocks of the Lower Muschelkalk are located at shallow depth southward of the fault.The top of the Lower Muschelkalk (mu) formation is located at 30.7-42.5 m depth below the surface northward of the fault in the study area.

The lithological units of Lower and Middle Muschelkalk correspond to the international chronostratigraphic stage of Anisian and Upper Muschelkalk to Ladinian, respectively.

The hydrogeological settings of the study area are characterized by fracture flow in a carstic network of the dolomitic Upper Muschelkalk layers. It is supposed that groundwater flows through the spaces in the dolomites, accumulates on the underlying less conductive Middle Muschelkalk, and is drained in the landslide mass where it occasionally reappears as springs. In the study area, several groundwater springs can be observed discharging from the landslide mass deposits (Figure 2a). Additional water supply for the springs is provided by the Kelsbach Creek that flows on the plateau at the rear of the dolomite cliff (Figure 2a). The creek completely disappears in the dolomite massif, and only during periods of intensive rainfall is a surplus of water drained through the creek bed to the Mosel River. Tracer tests carried out in 1968 confirmed the presence of the karstic network in the dolomitic rock massif, resulting in a groundwater flow from Kelsbach Creek to the springs in the landslide's area [44].

Previous studies describe preferential flow in the dolomites of Upper Muschelkalk, whereas the marls of Middle Muschelkalk are supposed to be less conductive material [44]. Therefore, the initial conceptual hydrogeological model of the study site assumed intense groundwater flow discharging from the dolomites and following the way through the landslide mass cover toward the Mosel River. However, the field studies described later below indicated that an intense preferential flow in the marls can occur as well, as it is shown in Figure 2b. 




(a)

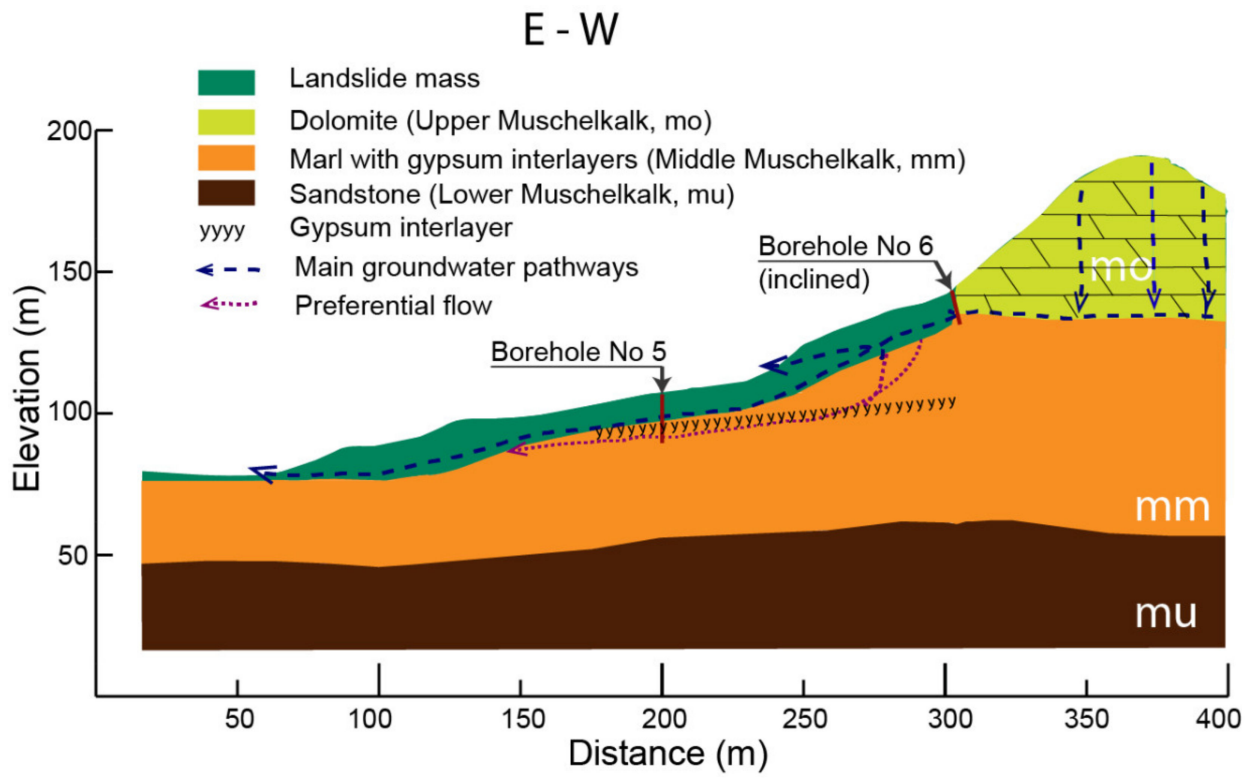

(b)

Figure 2. (a) Geological sketch of the landslide area showing distribution of boreholes and groundwater springs (b) geological section of the area showing conceptual hydrogeological settings (processed from $[42,43])$. 


\section{Materials and Methods}

In this study, geological and hydrogeological survey techniques were applied in conjunction with geophysical methods to investigate the hydrogeological conditions of the study site. The geophysical techniques were applied with particular focus on preferential flow, with a scope to identify and parametrize the flow pathways in the subsurface. Subsequently a hydrogeological model considering preferential pathways was compiled and validated through observed groundwater heads in piezometer wells.

In addition to 11 boreholes conducted during previous research campaigns $[39,40]$ in the study site, new boreholes 1-8 were drilled (Figure 2a) with a core driller, and samples were stored in boxes. The depth of the drillings was set two meters below the landslide mass-marl interface. The new boreholes Nos 1-8 and the 11 previous borehole records were used for the building of a 3D geological model applying GeoModeller software (Figure 1c,d). Further piezometers were installed in the new boreholes 1-7 (Figure 2a) equipped with barometric sounds measuring groundwater heads at a frequency of $15 \mathrm{~min}$.

The measurements of the groundwater heads are available for the time period from 7 March 2018 to 1 April 2019. The measurements were extended over a period of one year to consider seasonal fluctuation of the groundwater table.

Injection tests were conducted in boreholes No 3 and 5 (Figure 2). These boreholes were selected because preferential flow was expected there due to a loud noise of flowing water and almost constant observed groundwater heads. Water was pumped into the boreholes at an average rate of $0.8 \mathrm{~L} / \mathrm{sec}$; however, no increase of the groundwater table was attained.

Two geophysical techniques, ERT and self-potential mapping, were used for exploration of the hydrogeological settings of the study site. The ERT was used for the location of groundwater bodies, while self-potential mapping was selected for identification of groundwater flow in the subsurface. These two geoelecterical methods are complimentary and have been successfully applied for hydrogeophysical exploration [35].

The basic principle of ERT can be explained through four electrode measurements; namely, an electrical current is injected into the ground through two electrodes and voltage is measured between the second two [34]. An apparent resistivity of the ground can be calculated from applied current and measured voltage between the electrodes. When changing the arrangement of the electrodes, characteristics such as penetration depth, resolution, accuracy etc. can be varied [37]. An inversion procedure is applied to convert the pseudosection into a true resistivity section for a heterogeneous subsurface [34,37].

As the charge carrier in most soils is electrolytic groundwater and mineral-grain interfaces, ERT can be effectively applied for the identification of groundwater in the subsurface $[24,34,35]$. In the study site of Deisermillen, an ERT survey with 13 profiles was conducted using a LIPPMANN 4-point light $10 \mathrm{~W}$ device. Using a maximum number of 50 electrodes with $2 \mathrm{~m}$ electrode spacing and a maximum profile length of $100 \mathrm{~m}$ allowed the attainment of approximately $15 \mathrm{~m}$ penetration depth. However, the length and number of electrodes varied because blocks of rock or intense vegetation crossed the way. The position of the first profile's start and end points was georeferenced using a GNSS receiver (HiPer HR Topcon Deutschland Positioning GmbH, Hamburg, Germany). Horizontal accuracy of the GNSS measurement did not exceed $1 \mathrm{~m}$ during the fieldwork. A further 12 additional profiles were aligned parallel to the first profile using measuring tape, wooden sticks, and wires. The ERT profiles were orientated perpendicularly to the expected direction of groundwater flow, and $4 \mathrm{~m}$ spacing was set between the profiles. The surveys were conducted using Wenner electrode allocation due to a high signal-to-noise ratio [37]. The ZondRes3D software was used for creating a joint 3D ERT model from 13 profiles. Before inversion data were processed with the ZondRes Quality control module, unrealistic data points were removed. Ten inversion iterations were applied to maximally reduce the difference between observed and calculated apparent resistivity.

Streaming potential is one of the sources causing self-potential signals, which are triggered by the movement of electrolytic groundwater in porous media [34]. The magnitude 
of the streaming potential can range up to $100 \mathrm{mV}$ [37]. Moreover, in unconfined aquifers along the preferential flow path, a negative anomaly can be observed in the upstream, and a positive anomaly can be observed in the downstream part of the flow path $[18,34]$. When conducting the self-potential measurements, the base electrode is commonly kept in a fixed location as a reference, while the removable electrode is replaced along a specified raster [34]. Initially, self-potential mapping with a coarse raster of $2 \times 5 \mathrm{~m}$ was conducted for the identification of locations with self-potential anomalies in the study area. Further in the location of anomalies, measurements were repeated with a refined raster of $2 \times 2 \mathrm{~m}$. A regular measurement raster composed of several separated plots was marked in the field using measuring tape, wires, and wooden sticks. Furthermore, the corner points of the each plot were georeferenced using a GNSS receiver. Two $\mathrm{Ag} / \mathrm{AgCl}$ non-polarizing electrodes and a high impedance voltmeter with a sensitivity of $0.1 \mathrm{mV}$ were used. The repeatability of the self-potential measurements in the locations of the anomalies was validated over a period of one year, and regular measurements showed that the anomalies remain stable.

A 3D geological model was developed to provide a geological context for the interpretation of geophysical measurements. GeoModeller software was employed for the building of a 3D geological model applying 19 boreholes. Layer interfaces from the 3D geological model were further used for the building of a hydrogeological model. The 3D hydrogeological model with a focus on preferential flow was developed (Figure 3). The aim of the model was to find a physically-based explanation for observed groundwater heads by applying different subsurface flow mechanisms. When only flow in porous media was simulated, we were not able to explain the observed groundwater flow in the strata of less conductive marl; therefore, preferential flow was considered in the model's simulations. A discrete fracture modeling approach applying the HydroGeoSphere software was used. The HydroGeoSphere (HGS) is a 3D fully-integrated surface and subsurface flow simulator $[45,46]$, and with this, surface flow and subsurface flow in porous, fractured, and dual media for both saturated and unsaturated conditions can be modeled [45]. This allows for the application of the HGS code for advanced simulations in the vadose zone [47-49]. A detailed explanation of the governing equations used in the HGS code are available in the HGS user manual [46] and in a publication by Brunner and Simmons [45].

In the hydrogeological simulation, the recharging of groundwater in the model's domain occurs through the first-type boundary condition of the rainfall rate, which is applied to the model's surface domain (Figure 3a). Initially, the average precipitation amounts were applied for a period of several years, which allowed for the saturation of the model's domain. Furthermore, daily precipitation amounts observed by the meteorological observation station of Nittel from 7 March 2018 to 1 April 2019 were used in the model [50]. The first-type (Dirichlet) boundary condition of the prescribed hydraulic head was applied in the eastern part of the model's domain to consider the infiltration of groundwater from the Mosel River, and also in the western part, which was equal with the groundwater table in borehole No 6 to consider the afflux of groundwater from the carstic network in the eastern part. We assume that the discharge of groundwater from the carstic network in the dolomite cliff occurs in a narrow zone where springs occur (Figure 2a). To the outer boundary of the model's domain, a critical depth boundary condition was applied, which allowed water to leave the model's domain without influencing the upstream groundwater heads or surface water depths [46]. The morphology of the preferential flowpath in the model was assumed to be a $7 \mathrm{~mm}$ thin, lateral conduit dissecting borehole No 5 where intense preferential flow was located (Figure 3c). The width of the conduit was arbitrarily assumed. The conduit was laterally embedded in the marl strata until it reached the marl-landslide mass interface. Furthermore, the conduit followed the interface allowing the drainage of water toward Mosel River. The model's structural sublayering was adopted to the above explained conceptual model of the flowpath (Figure 3b). A discrete fracture modeling approach was employed for the simulation of groundwater flow in the preferential flowpath. An exchange between the fracture and the encompassing 
matrix was considered in the HydroGeoSphere simulation, meaning that the saturation of the fracture can vary depending on afflux from the encompassing porous media [46].

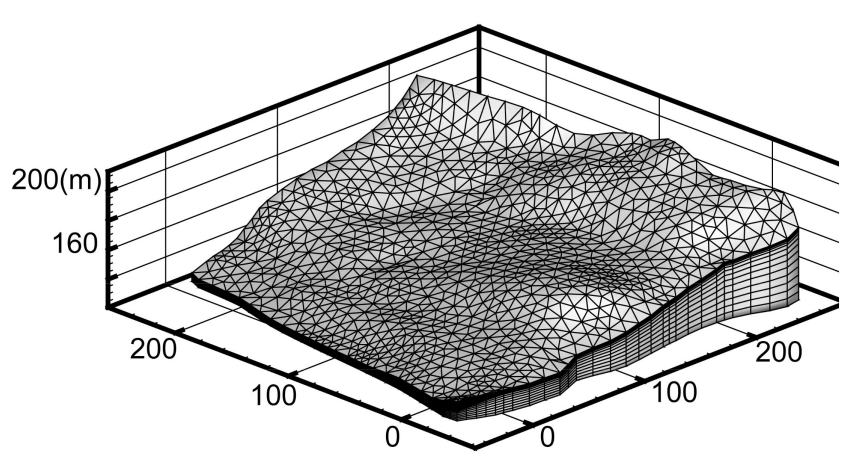

(a)

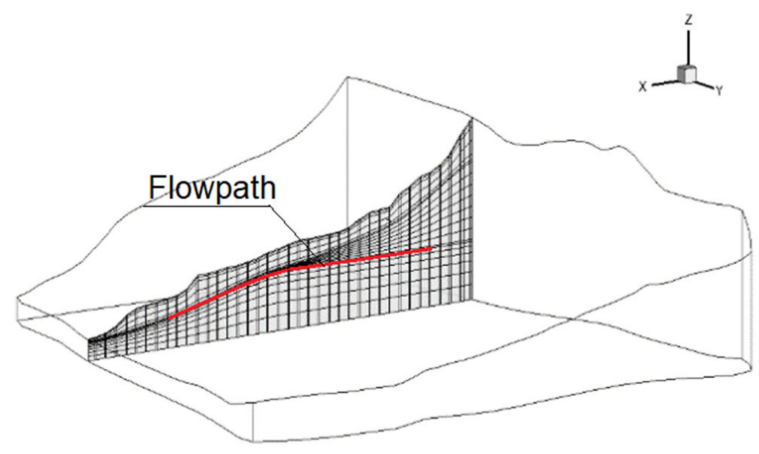

(b)

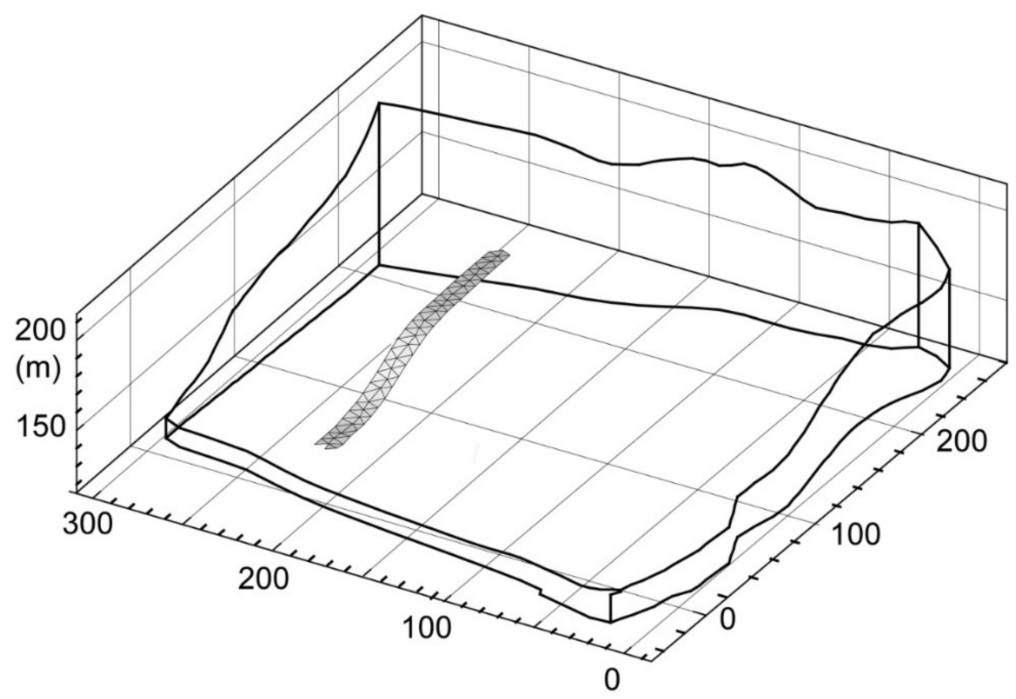

(c)

Figure 3. (a) The structure of the hydrogeological model, (b) the model's sub layering, (c) morphology of the lateral flowpath.

\section{Results}

From a hydrogeological viewpoint, the two most conductive geological units in the study site are the carstic dolomites and the overlaying conductive landslide mass. However, field investigation revealed that in the strata of less conductive marls highly permeable conduits exist. Figure 4 illustrates that two systems of groundwater flow are present, namely one above the less conductive marls and another in the marl sediments, which itself is represented by boreholes 3 and 5 .

Boreholes 3, 5, and partially also 4 and 6 have an untypical temporal variability of their hydraulic heads, because independently of precipitation, their hydraulic heads remain constant. This is especially emphasized in borehole No 5. In boreholes No 3 and 5 (Figure 4), a loud noise of rapidly flowing water can be heard. Further pumping tests were conducted in these boreholes to get detailed insights about the possible causes of such an untypical behavior of groundwater in the boreholes. An injection test with a flowrate of $0.8 \mathrm{~L} / \mathrm{s}$ was conducted in boreholes No. 3 and 5; however, no increase of the groundwater head could be observed there. This indicates that very highly conductive conduits in the low permeable deposits of the marls exist. This phenomenon is also confirmed by the previous borehole records available in the archive of the Geological Survey of Luxembourg [40]. Namely, in borehole S7 at a depth of 24.5 to $25.10 \mathrm{~m}$ and in borehole S6 (Figure 2a) at a depth of 18.6 to $19.25 \mathrm{~m}$, a cavity was identified [40]. Unfortunately, no detailed description 
of these cavities is present. Drawings of the cores indicate that the cavities are located in the proximity of gypsiferous interlayers. Therefore, it can be speculated that the preferential flowpaths in the new boreholes No 3 and 5 are also caused by dissolution of the gypsiferous interlayers. After a detailed analysis of the new drillcore records in borehole No 5, a thin gypsum interlayer was discovered at the same depth where preferential groundwater flow occurs (Figure 5). For detailed insight into the geological settings, a geological section through borehole No 5 was drawn (Figure 2b).

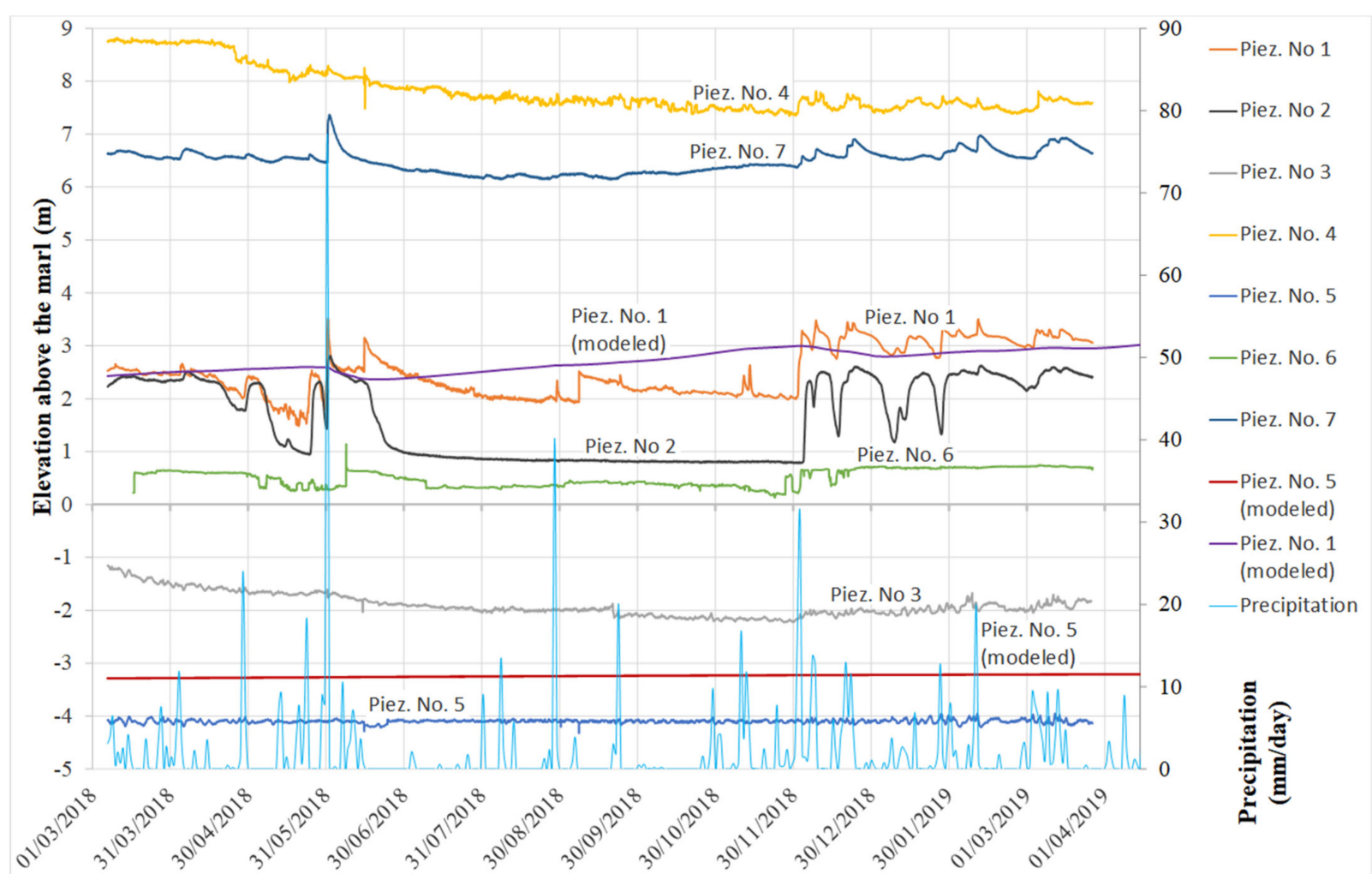

Figure 4. Temporal changes of the groundwater heads in piezometer wells Nos 1-7 from 7 March 2018 to 1 April 2019. 0-elevation corresponds with the surface of the marl.

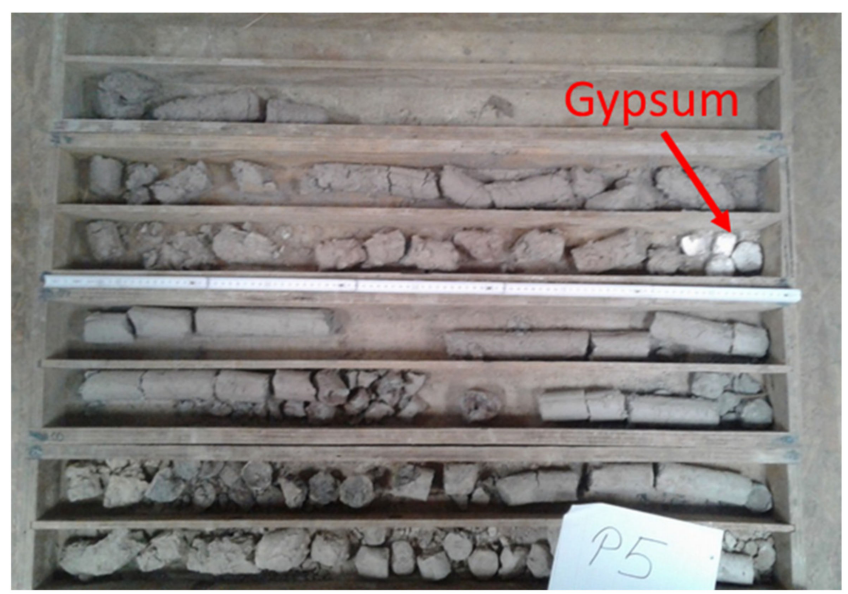

Figure 5. Gypsum interlayer in the core records of borehole No 5.

Both ERT and self-potential mapping were used to obtain detailed information about the preferential flowpaths in the study area. The ERT was employed for the identification of groundwater bodies caused by groundwater discharging from the carstic network and flowing downslope through the landslide mass to the Mosel River. The self-potential 
mapping was used for the identification of streaming potential caused by preferential groundwater flow.

The results of the self-potential mapping are explicitly illustrated in Figure 6. Relatively homogenous self-potential values can be observed in the northern part of the study area; however, downslope from the discharge area of groundwater springs, emphasized self-potential anomalies are present. Several couples of positive and negative self-potential anomalies can be observed in the study site (Figure 6). The maximum magnitude of the self-potential signal exceeds approximately $-103 /+98 \mathrm{mV}$. The polarity, magnitude, and orientation of the self-potential anomalies indicate that they might be caused by the streaming potential. In Figure 6, the main self-potential anomalies are marked by blue arrows. They are orientated in the direction of the expected groundwater flow with a positive polarity downslope. An exception is the anomaly in the southern part, which is probably associated with a groundwater flowpath adjoining the main pathway. A closer look at the subsurface morphology of the less conductive marl indicates a local depression that corresponds with the direction of the supposed streaming potentials. It can be speculated that the surface of the marl constrains groundwater flow, which corresponds with the direction of the measured streaming potentials.



Figure 6. Location self-potential mapping in the study area. 
The intense preferential flow within the marls, as revealed in boreholes No 3 and 5, may not cause the streaming potential anomalies. Possibly self-potential signals occur due to groundwater flow in the conductive landslide mass directed by the topography of the underlain marl surface.

When considering the ERT model, highly conductive zones can be observed in deeper sections of the ERT survey while low conductivities can be observed in the uppermost part (Figure 7). Moreover, the less conductive zones are more fragmented, as they may perhaps represent landslide mass in the unsaturated zone with large spaces between the dolomite blocks resulting in increased electrical resistivity. Highly conductive zones are better connected as they may be related through groundwater pathways (Figure 7a,c).

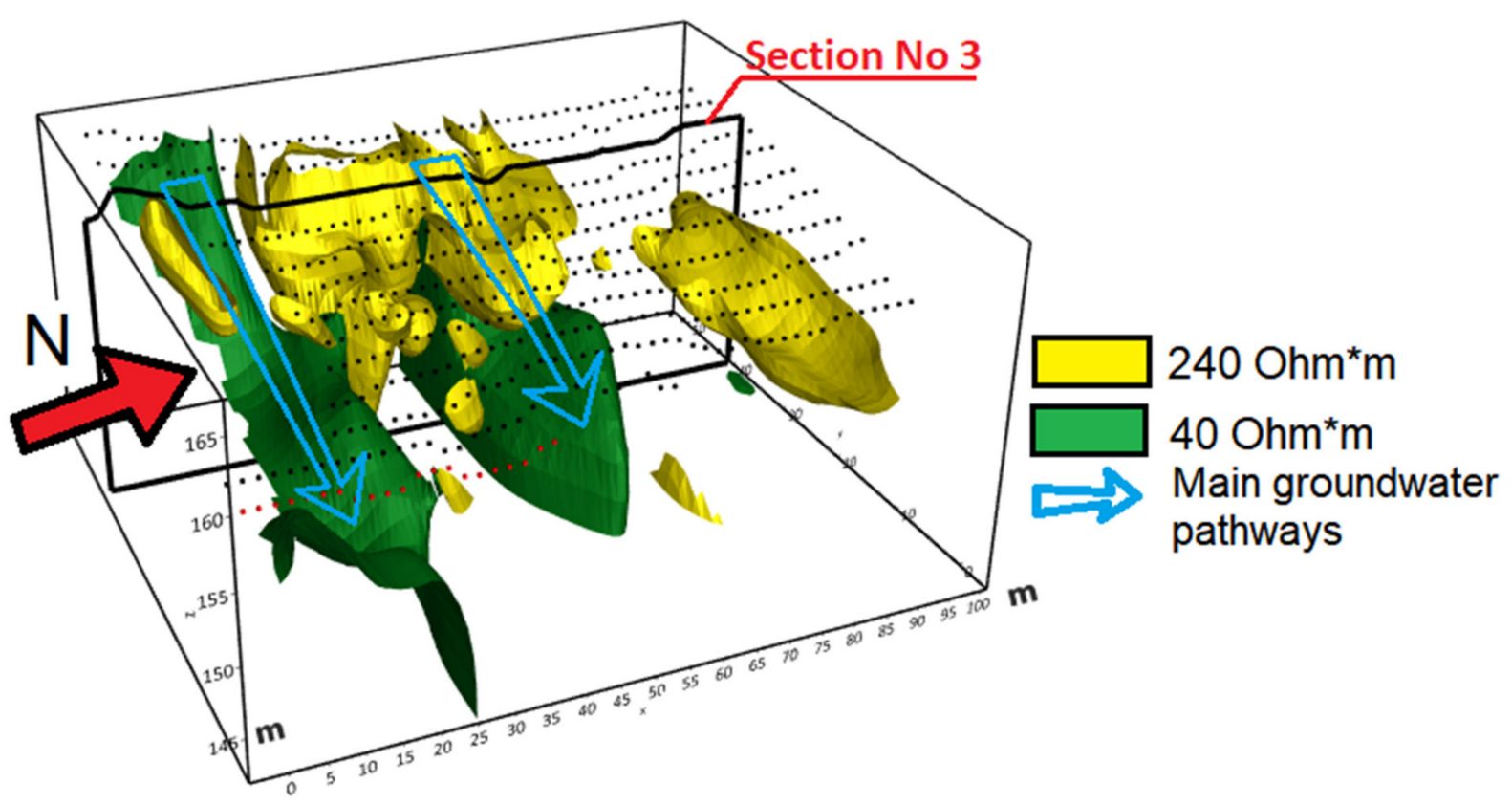

(a)

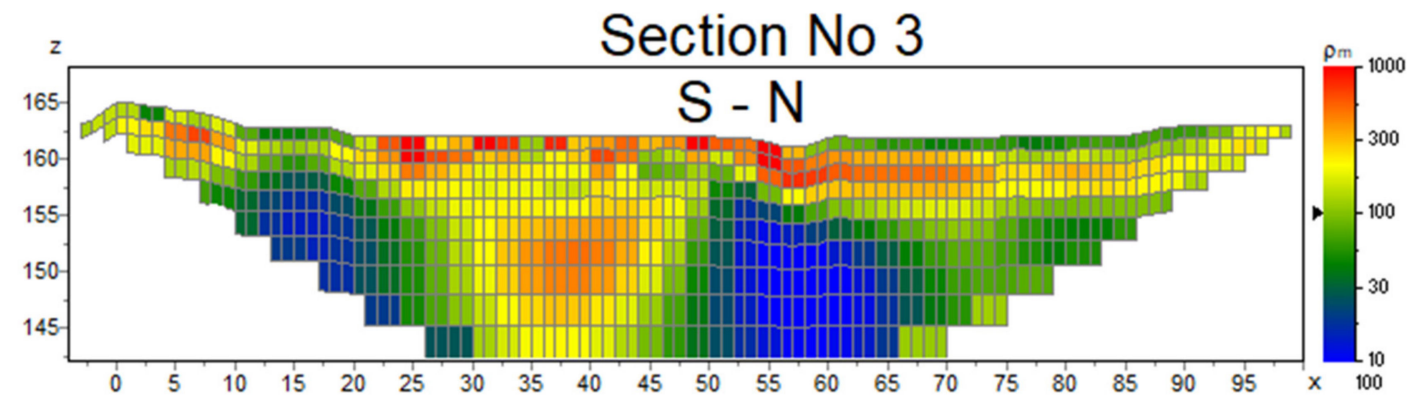

(b)

Figure 7. Cont. 


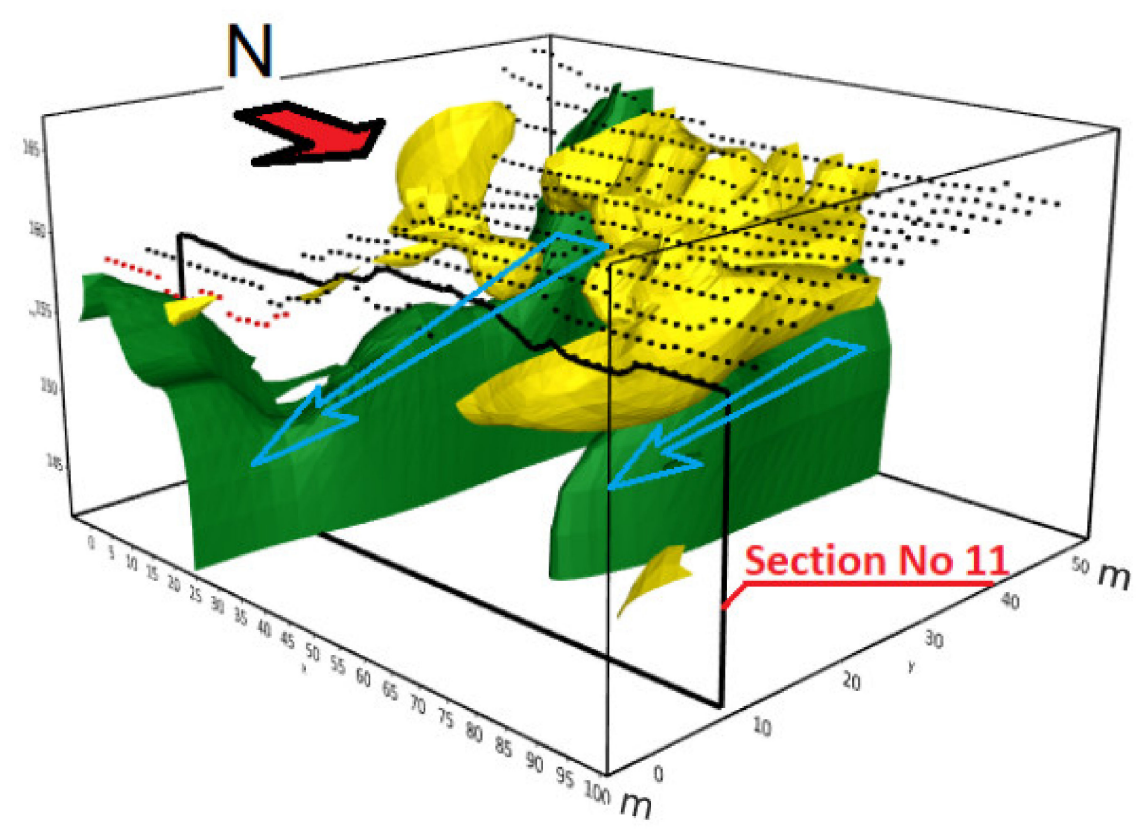

(c)

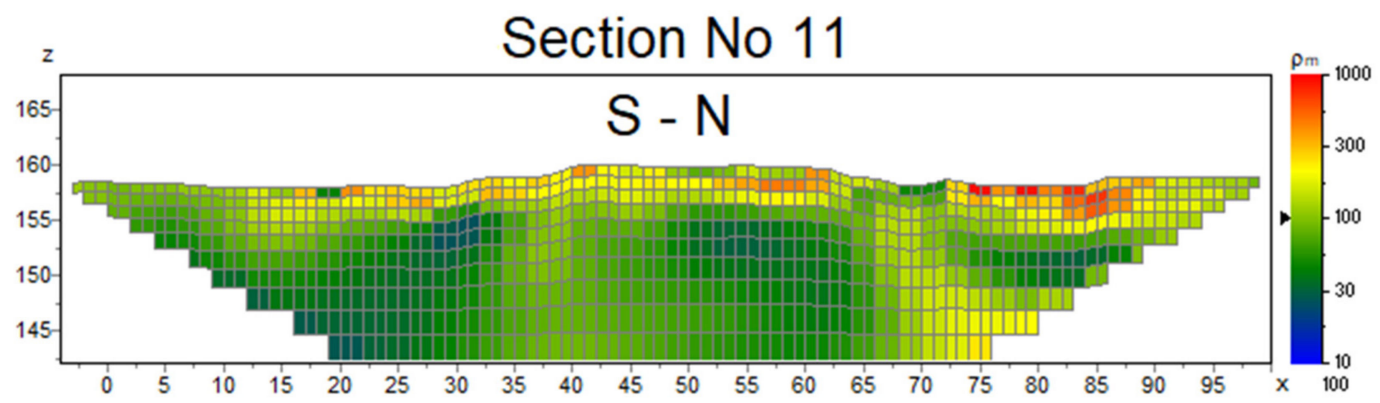

(d)

Figure 7. Three-dimensional (3D) high and low resistivity zones in the subsurface created through the inversion of 13 ERT profiles. The 3D model in view from (a) SE and (c) NE (the black dots represent the location of each electrode) and two characteristic sections (b) No 3 and (d) No 11 of the 3D model.

A 3D hydrogeological model of the study site was compiled for the time period from 7 March 2018 to 1 April 2019 when the results of groundwater monitoring were available. This 3D model considering preferential flow was compiled for the simulation of groundwater flow in the conductive marl. The hydrogeological model considered daily precipitation rates and saturated and unsaturated flow both in porous and fractured media.

In the hydrogeological model, a $7 \mathrm{~mm}$ thin lateral conduit was embedded in the layer of marls intersecting borehole No 5 where the most pronounced preferential groundwater flow was observed (Figure 2b).

Modeled groundwater heads in two observation points corresponding with boreholes No 1 and 5 are illustrated in Figure 4. In borehole No 1, flow in porous media can be observed; both observed and simulated heads indicate response to precipitation events, which is not the case in borehole No 5 where preferential flow occurs. The groundwater simulation with the thin laterally extending conduit allowed for the attainment of an exact correspondence between the modeled and observed groundwater heads in piezometer well No 5, where preferential flow occurs. 


\section{Discussion}

This study was conducted in a study site in the valley of Upper Mosel, Luxembourg, where mass movements are frequently present. The aim of the study was to explore the hydrogeological conditions of a slope affected by a recent landslide.

Observations of the groundwater heads in piezometer wells indicated very diverse responses to changing precipitation in the study site. The almost constant hydraulic heads with high flow rates in two boreholes could be explained through preferential flow in the marl strata. The dissolution of gypsum could have caused thin, lateral conduits in the marl deposits. In boreholes No 3 and 5, constant groundwater heads are sustained because water discharges into these conduits.

In the inclined borehole No 6, which was installed in the dolomite cliff (Figure 2b), alternation between the two governing groundwater heads can be observed (Figure 4). This phenomenon could be explained through presence of two fracture planes dissecting the piezometer's screen. Possibly if the conductivity of the lowest conduit is relatively low and high inflow of groundwater occurs, the level of the next lateral conduit is reached where it remains stable until the water inflow decreases.

Hydrogeological field testing and observations in boreholes at the field site also revealed that preferential flowpaths have high flow capacity. However, the piezometer observations delivered no information about the morphology and spatial extension of preferential flowpaths.

The newest 3D geophysical surveys are promising techniques for the investigation of the morphology of subsurface flowpaths. The 3D ERT indicated possible locations of saturated groundwater bodies associated with preferential flow heading toward the Mosel River; however, the resistivity method was not able to detect increased flowrate in the subsurface, which is characteristic of preferential flow. The self-potential method was employed for the measurement of streaming potentials associated with preferential flow into the subsurface. When integrating both geophysical methods-ERT and self-potentialconducted in the study area, it can be observed that the main groundwater pathways toward the Mosel River start from spring discharges (Figures 6 and 7). Both geophysical methods reveal self-potential anomalies and highly conductive zones in the same locations. Two main groundwater pathways starting from spring discharge could be recognized both in the ERT and self-potential surveys. The pathway in the northern part disappears from geophysical surveys; perhaps it diverges or moves toward deeper layers in the marls. The pathway in the southern part continues in both surveys through the study area toward the Mosel River.

The aforementioned field research allowed the measurement of signals associated with preferential flow such as steaming potentials and the increase of electrical conductivity along the flowpath; however, possible signals of flowing groundwater are diffusely spread over a relatively large area. Despite intensive testing, the morphology of the flowpath remained unclear. A detailed analysis of the drillcores indicated that a possible cause of intense preferential flow may be the dissolution of gypsum interlayers in the marls of Middle Muschelkalk. Thin, laterally extended conduits, caused by the dissolution of the gypsum, are proposed as the most likely morphological shapes of preferential flow. To validate this hypothesis, a 3D hydrogeological model considering flow both in porous and fractured media was developed. This model with a lateral preferential flow path embedded in a porous matrix (Figure 3c) provides an excellent correspondence with observations in piezometers where preferential flow is present. Nevertheless, many unknowns still remain such as lateral extension, aperture, or the discharge location of the flowpath. Furthermore, the impact of the hydrogeological settings on the stability of the slope is unclear and will be investigated in a separate article.

In the future, advanced field testing with a higher injected water amount could allow for the determination of flow capacity in the flowpath. Field tests integrated with a numerical groundwater model would allow for the estimation of the aperture of the flowpath. However, an injection test should be conducted with particular caution because 
the injection of high water amounts in a landslide prone slope could cause the reactivation of the landslide. Recent advances in the modeling of the self-potential signals could allow estimating the groundwater seepage velocity, which can be used for validation of the hydrogeological model.

This study shows that an integrated research program including hydrogeological monitoring, hydrogeological field testing, and geological and geophysical exploration could be necessary for the exploration of preferential groundwater flow. Despite recent advances in geophysical exploration, the determination of an exact morphology for preferential flowpaths is not straightforward. The newest hydrogeological models are able to conduct fully integrated simulations of preferential groundwater flow. By adopting the hydrogeological model to observations, the site's hydrogeological settings can be explored in a very detailed scale. Thus, numerical models allow for better conceptualization and parametrization of preferential flowpaths in the subsurface.

\section{Conclusions}

Hydrogeological investigation methods in combination with geophysical prospecting were used for the investigation of the hydrogeological settings of a landslide-prone slope in the Upper Mosel valley.

Observations in piezometer wells show that in the Deisermillen study site, two groundwater flow systems are present: the first being groundwater flow above the less permeable marls and the second located within the marl sediments where preferential flow occurs. Hydrogeological observations in piezometer wells and hydrogeological testing revealed an intense preferential flow in the less conductive marls, which was not expected to occur there. Nevertheless, observations in boreholes are 2D measurements which are not suitable for the complete exploration of heterogeneous groundwater flow conditions.

A geophysical investigation was also conducted for the investigation of the spatial extension of flowpaths in the subsurface. By applying ERT and self-potential mapping techniques, preferential flow could have been identified in a zone of the hillslope where groundwater from the carstic network enters the landslide mass cover and flows toward the Mosel River. However, it is not entirely clear which preferential flow system is the source of the measured self-potential anomalies because the signals are widely spread over a large area. As the interpretation of the geophysical measurements was not straightforward, assumptions based on the geological data were necessary for the conceptualization of the preferential flowpaths in the numerical model.

The hydrogeological model allowed for the validation of the assumed morphology of a thin, laterally extending preferential flowpath through field observations in piezometer wells.

The results of this study show that the identification and parametrization of the preferential flow using conventional techniques such as hydrogeological testing and monitoring can be ambiguous. Other data sources, such as knowledge about the local geological settings and numerical modeling could be necessary for better conceptualization and parametrization of preferential flow in the subsurface.

Integrated application of models, for instance geophysical techniques used for the validation of the hydrogeological simulations, can help to explore the preferential flow. Applying inverted streaming potential signals that the permeability and seepage velocity of the preferential flowpaths can be derived [33]. In the study area of Deisermillen, modeling of the streaming potential signals can be used for validation of the hydrogeological model during the subsequent research.

Author Contributions: Conceptualization, K.K. and J.-F.W.; methodology, K.K.; software, K.K.; validation, K.K. and J.-F.W.; formal analysis, K.K. and J.-F.W.; investigation, K.K.; resources, J.F.W.; data curation, K.K. and J.-F.W.; writing-original draft preparation, K.K.; writing-review and editing, J.-F.W.; visualization, K.K.; supervision, J.-F.W.; project administration, K.K.; funding acquisition, J.-F.W. All authors have read and agreed to the published version of the manuscript.

Funding: This research received no external funding. 
Institutional Review Board Statement: Not applicable.

Informed Consent Statement: Not applicable.

Data Availability Statement: Publicly available datasets were analyzed in this study. This data can be found here: https:/ / map.geoportail.lu/theme/main?lang=en\&version=3\&zoom=14\&X=716922 $\& Y=6389557 \&$ rotation=0\&layers $=1788-314-206 \&$ opacities $=0.75-1-1 \& b g$ Layer $=$ blank $($ accessed on 15 April 2021), https: / / www.agrimeteo.lu/_c12577b4003e3132.nsf/0/d6d6c28de01e95c7c1257dc600 436335? OpenDocument\&TableRow=10.1.1\#10.1 (accessed on 15 October 2020). Other data sources presented in this study are available on request from the corresponding author. The data are not publicly available because they were provided by a private company.

Acknowledgments: We would like to thank the staff members of the company EURASOL S.A. for their engagement and patience during the field work. Especially, we would like to acknowledge the contribution of director Robert Heintz who sponsored drilling works of eight boreholes in the study area and provided us with groundwater monitoring data over a period more than one year long. We would also like to thank geomorphology students of University of Trier, especially Mathias Jackel, Judith Koschorke, Stefan Habetz, Pascal Wintrich, and technical assistant Yannick Hausener, who helped during geophysical surveys and Robert Colbach and Birgit Kausch for supporting this study with archive materials. Finally, we would like to acknowledge researchers of the Centre for Hydrogeology and Geothermics of University of Neuchâtel, especially Professor Philip Brunner for the help with the modeling software.

Conflicts of Interest: The authors declare no conflict of interest. The funders had no role in the design of the study; in the collection, analyses, or interpretation of data; in the writing of the manuscript, or in the decision to publish the results.

\section{References}

1. Clothier, B.E.; Green, S.R.; Deurer, M. Preferential flow and transport in soil: Progress and prognosis. Eur. J. Soil Sci. 2008, 59, 2-13. [CrossRef]

2. Tsang, C.-F.; Neretnieks, I.; Tsang, Y. Hydrologic issues associated with nuclear waste repositories. Water Resour. Res. 2015, 51, 6923-6972. [CrossRef]

3. Birkholzer, J.T.; Mukhopadhyay, S.; Tsang, Y.Y.W. The Impact of Preferential Flow on the Vaporization Barrier Above Waste Emplacement Drifts at Yucca Mountain, Nevada. Nucl. Technol. 2004, 148, 138-150. [CrossRef]

4. Bolève, A.; Janod, F.; Revil, A.; Lafon, A.; Fry, J.-J. Localization and quantification of leakages in dams using time-lapse self-potential measurements associated with salt tracer injection. J. Hydrol. 2011, 403, 242-252. [CrossRef]

5. Ikard, S.J.; Rittgers, J.; Revil, A.; Mooney, M.A. Geophysical Investigation of Seepage Beneath an Earthen Dam. Groundwater 2015, 53, 238-250. [CrossRef]

6. Kukemilks, K.; Wagner, J.-F.; Saks, T.; Brunner, P. Conceptualization of preferential flow for hillslope stability assessment. Hydrogeol. J. 2018, 26, 439-450. [CrossRef]

7. Shao, W.; Bogaard, T.A.; Bakker, M.; Greco, R. Quantification of the influence of preferential flow on slope stability using a numerical modelling approach. Hydrol. Earth Syst. Sci. 2015, 19, 2197-2212. [CrossRef]

8. Shao, W.; Bogaard, T.; Bakker, M.; Berti, M. The influence of preferential flow on pressure propagation and landslide triggering of the Rocca Pitigliana landslide. J. Hydrol. 2016, 543, 360-372. [CrossRef]

9. Krzeminska, D.M.; Bogaard, T.A.; van Asch, T.W.J.; van Beek, L.P.H. A conceptual model of the hydrological influence of fissures on landslide activity. Hydrol. Earth Syst. Sci. 2012, 16, 1561-1576. [CrossRef]

10. Bogaard, T.A.; Greco, R. Landslide hydrology: From hydrology to pore pressure. WIREs Water 2016, 3, 439-459. [CrossRef]

11. Lu, N.; Godt, J.W. Hillslope Hydrology and Stability; Cambridge University Press: Cambridge, UK, 2013.

12. Noguchi, S.; Tsuboyama, Y.; Sidle, R.C.; Hosoda, I. Morphological Characteristics of Macropores and the Distribution of Preferential Flow Pathways in a Forested Slope Segment. Soil Sci. Soc. Am. J. 1999, 63, 1413-1423. [CrossRef]

13. Harp, E.L.; Wells, W.G., II; Sarmiento, J.G. Pore pressure response during failure in soils. GSA Bull. 1990, 102, 428-438. [CrossRef]

14. Nieber, J.L.; Warner, G.S. Soil pipe contribution to steady subsurface stormflow. Hydrol. Processes 1991, 5, 329-344. [CrossRef]

15. Stadler, L.; Hinkelmann, R.; Helmig, R. Modeling Macroporous Soils with a Two-Phase Dual-Permeability Model. Transp. Porous Media 2012, 95, 585-601. [CrossRef]

16. Beven, K.; Germann, P. Macropores and water flow in soils revisited. Water Resour. Res. 2013, 49, 3071-3092. [CrossRef]

17. Ellefsen, K.J.; Hsieh, P.A.; Shapiro, A.M. Crosswell seismic investigation of hydraulically conductive, fractured bedrock near Mirror Lake, New Hampshire. J. Appl. Geophys. 2002, 50, 299-317. [CrossRef]

18. Revil, A.; Cary, L.; Fan, Q.; Finizola, A.; Trolard, F. Self-potential signals associated with preferential ground water flow pathways in a buried paleo-channel. Geophys. Res. Lett. 2005, 32. [CrossRef] 
19. Uhlemann, S.; Kuras, O.; Richards, L.A.; Naden, E.; Polya, D.A. Electrical resistivity tomography determines the spatial distribution of clay layer thickness and aquifer vulnerability, Kandal Province, Cambodia. J. Asian Earth Sci. 2017, 147, 402-414. [CrossRef]

20. Yeh, H.-F.; Lin, H.-I.; Wu, C.-S.; Hsu, K.-C.; Lee, J.-W.; Lee, C.-H. Electrical resistivity tomography applied to groundwater aquifer at downstream of Chih-Ben Creek basin, Taiwan. Environ. Earth Sci. 2015, 73, 4681-4687. [CrossRef]

21. Pidlisecky, A.; Moran, T.; Hansen, B.; Knight, R. Electrical Resistivity Imaging of Seawater Intrusion into the Monterey Bay Aquifer System. Groundwater 2016, 54, 255-261. [CrossRef]

22. Colombero, C.; Baillet, L.; Comina, C.; Jongmans, D.; Vinciguerra, S. Characterization of the 3-D fracture setting of an unstable rock mass: From surface and seismic investigations to numerical modeling. J. Geophys. Res. Solid Earth 2017, 122, 6346-6366. [CrossRef]

23. National Research Council. Rock Fractures and Fluid Flow: Contemporary Understanding and Applications; The National Academies Press: Washington, DC, USA, 1996; p. 568.

24. Roubinet, D.; Irving, J. Discrete-dual-porosity model for electric current flow in fractured rock. J. Geophys. Res. Solid Earth 2014, 119, 767-786. [CrossRef]

25. Hubbard, S.S.; Linde, N. 2.15-Hydrogeophysics. In Treatise on Water Science; Wilderer, P., Ed.; Elsevier: Oxford, UK, 2011; pp. 401-434.

26. Roubinet, D.; Linde, N.; Jougnot, D.; Irving, J. Streaming potential modeling in fractured rock: Insights into the identification of hydraulically active fractures. Geophys. Res. Lett. 2016, 43, 4937-4944. [CrossRef]

27. Jougnot, D.; Jiménez-Martínez, J.; Legendre, R.; Le Borgne, T.; Méheust, Y.; Linde, N. Impact of small-scale saline tracer heterogeneity on electrical resistivity monitoring in fully and partially saturated porous media: Insights from geoelectrical milli-fluidic experiments. Adv. Water Resour. 2018, 113, 295-309. [CrossRef]

28. Blazevic, L.A.; Bodet, L.; Pasquet, S.; Linde, N.; Jougnot, D.; Longuevergne, L. Time-Lapse Seismic and Electrical Monitoring of the Vadose Zone during a Controlled Infiltration Experiment at the Ploemeur Hydrological Observatory, France. Water 2020, 12, 1230. [CrossRef]

29. Fournier, C. Spontaneous potentials and resistivity surveys applied to hydrogeology in a volcanic area: Case history of the Chaîne des Puys (Puy-de-Dôme, France). Geophys. Prospect. 1989, 37, 647-668. [CrossRef]

30. Birch, F.S. Imaging the Water Table by Filtering Self-Potential Profiles. Groundwater 1998, 36, 779-782. [CrossRef]

31. Perrier, F.E.; Petiau, G.; Clerc, G.; Bogorodsky, V.; Erkul, E.; Jouniaux, L.; Lesmes, D.; Macnae, J.; Meunier, J.M.; Morgan, D.; et al. A One-Year Systematic Study of Electrodes for Long Period Measurements of the Electric Field in Geophysical Environments. J. Geomagn. Geoelectr. 1997, 49, 1677-1696. [CrossRef]

32. Soueid Ahmed, A.; Revil, A.; Steck, B.; Vergniault, C.; Jardani, A.; Vinceslas, G. Self-potential signals associated with localized leaks in embankment dams and dikes. Eng. Geol. 2019, 253, 229-239. [CrossRef]

33. Ahmed, A.S.; Revil, A.; Bolève, A.; Steck, B.; Vergniault, C.; Courivaud, J.R.; Jougnot, D.; Abbas, M. Determination of the permeability of seepage flow paths in dams from self-potential measurements. Eng. Geol. 2020, 268, 105514. [CrossRef]

34. Everett, M.E. (Ed.) Near-Surface Applied Geophysics; Cambridge University Press: Cambridge, UK, 2013.

35. Revil, A.; Jardani, A. The Self-Potential Method: Theory and Applications in Environmental Geosciences; Cambridge University Press: Cambridge, UK, 2013.

36. Jouniaux, L.; Maineult, A.; Naudet, V.; Pessel, M.; Sailhac, P. Review of self-potential methods in hydrogeophysics. Comptes Rendus Geosci. 2009, 341, 928-936. [CrossRef]

37. Knödel, K.; Krummel, H.; Lange, G. (Eds.) Geophysik; Springer: Berlin/Heidelberg, Germany, 1997.

38. Heyl, K.-E. Ein Hangrutsch bei Nittel (Obermosel). Notizenblatt des Hessischen Landesamtes für Bodenforschung zu Wiesbaden; Hessian Agency for the Environment and Geology: Wiesbaden, Germany, 1971; Volume 99, pp. 347-360.

39. Bintz, J. Raport Géologique Concerne: Situation Geologiques au Glissement "Deysermühle"; Service Géologique, Administration des Ponts et Chaussées: Luxembourg, 1965.

40. Johan Keller GmbH. Sanierung Rutschung Deysermühle. Aufschluß und Pegelbohrungen; Service Géologique, Administration des Ponts et Chaussées: Luxembourg, 1974.

41. OpenStreetMap Contributors, and the GIS User Community; World Street Map, Esri: Redlands, CA, USA, 2017.

42. Service Géologique, Administration des Ponts et Chaussées. Droits Réservés à l'Etat du Grand-Duché de Luxembourg; Service Géologique, Administration des Ponts et Chaussées: Luxembourg, 2020.

43. Administration du Cadastre et de la Topographie. Droits Réservés à l'Etat du Grand-Duché de Luxembourg. Available online: https: / / map.geoportail.lu/theme $/$ main?lang=en\&version=3\&zoom $=14 \& X=716922 \& Y=6389557 \&$ rotation=0\&layers= 1788-314-206\&opacities=0.75-1-1\&bgLayer=blank (accessed on 15 April 2021).

44. Neumann-Redlin, C. Hydrogeologische und Hydrochemische Untersuchungen im Oberen Muschelkalk und Keuper Luxemburgs. EberhardKarls-Universität zu Tübingen; Service Géologique du Luxembourg: Luxembourg, 1971; Volume 22, pp. 1-87.

45. Brunner, P.; Simmons, C.T. HydroGeoSphere: A Fully Integrated, Physically Based Hydrological Model. Groundwater 2012, 50, 170-176. [CrossRef]

46. Aquanty Inc. HydroGeoSphere: User Manual, Release 1.0; Aquanty Inc.: Waterloo, ON, Canada, 2013.

47. Banks, E.W.; Brunner, P.; Simmons, C.T. Vegetation controls on variably saturated processes between surface water and groundwater and their impact on the state of connection. Water Resour. Res. 2011, 47. [CrossRef] 
48. Schilling, O.S.; Doherty, J.; Kinzelbach, W.; Wang, H.; Yang, P.N.; Brunner, P. Using tree ring data as a proxy for transpiration to reduce predictive uncertainty of a model simulating groundwater-surface water-vegetation interactions. J. Hydrol. 2014, 519, 2258-2271. [CrossRef]

49. Xie, Y.; Cook, P.G.; Brunner, P.; Irvine, D.J.; Simmons, C.T. When Can Inverted Water Tables Occur Beneath Streams? Groundwater 2014, 52, 769-774. [CrossRef] [PubMed]

50. Agrarmeteorologie Luxemburg. Wetterstation Nittel. Available online: https://www.agrimeteo.lu/_c12577b4003e3132.nsf/0/ d6d6c28de01e95c7c1257dc600436335?OpenDocument\&TableRow=10.1.1\#10.1 (accessed on 15 October 2020). 